\title{
Comparing the compressive strengths of concrete made with river sand and quarry dust as fine aggregates
}

\author{
Chijioke Chiemela ${ }^{1}$, Igwegbe Walter ${ }^{1}$, Ibearugbulem Ogedi ${ }^{1}$, \\ Okoye Peter ${ }^{2}$, Oke Mong ${ }^{2}$ \\ ${ }^{1}$ Civil Engineering Department, Federal Polytechnic Nekede, Owerri, Imo State, Nigeria \\ ${ }^{2}$ Mechanical Engineering Department, Federal Polytechnic Nekede Owerri Imo State, Nigeria
}

\begin{abstract}
Nowadays development of infrastructures is becoming number one priority in the world, particularly in the developing countries. So there are great demands within the construction industries for river sand as fine aggregate used in the production of concrete. This has created a very difficult situation; the cost of river sand has increased and also there is great fear from environmentalist and ecologist that in the future there may be scarcity of river sand and the environment and the ecology will be distorted. Hence, the need to find materials which are affordable and available to partially or totally replaced river sand in the production of concrete. This work is focused on the use of quarry dust as a total replacement to river sand in the production of concrete, and comparing the results (compressive strength) to that obtained from conversional concrete made with river sand.
\end{abstract}

Keyword: Quarry dust; river sand; compressive strength; water cement ratio; workability

\section{INTRODUCTION}

Concrete is a mixture of water, cement or binder and aggregates (fine and coarse aggregate) and is a commonly used material for construction (Barritt, 1984). River sand has been the most popularly used fine aggregate in the production of concrete, but due to the overuse of the material, our environment is the worst hit, also the price of river sand has soar in recent times (Sukesh, at el 2013). Unfortunately, the effect of quarry dust content in aggregates on properties of fresh and hardened concrete are not well known (Tahir and Khaled, 1999). A huge amount of quarry dust produced during the crushing of quarry stones in the quarry industries is often considered as waste and is often used as landfills (Rashid, at el, 2013). The construction industries in the developing world is looking for alternative materials that can replace the demand for natural sand, thereby reduce environmental load and waste management lost, reduction of production cost as well as augmenting the quality of concrete (Lohan, et al 2012).

Compressive strength is the criterion for the determination of the quality of concrete (Troxel, et al 1968) and as such it becomes necessary that for a concrete to be used, its compressive strength has to be determined. So here comparison is made between the compressive strength of concrete made with river sand and that made with quarry dust as fine aggregate in the production of concrete. 


\section{MATERIAL AND METHOD}

The river sand used in this work was obtained from Otamiri River in Owerri, Imo state Nigeria, the quarry dust and the coarse aggregate were obtained from Abakaliki in Ebonyi state Nigeria, the cement used was Dangote cement bought from the cement shop and the water used was obtained from pipe borne water from the Federal Polytechnic Nekede Owerri Imo state. All the fine aggregates were washed thoroughly to remove unwanted debris and later dried.

The fine aggregates were graded in accordance with BS 812 part 1:1975. The coarse aggregate was crushed granite chippings of $20 \mathrm{~mm}$ normal size and the cement conformed to BS 12. The river sand and the quarry dust used were those passing sieve $2 \mathrm{~mm}$ and retained on sieve $150 \mu \mathrm{m}$ and the coarse aggregate (granite chipping) was passed through sets of sieve and passing through sieve $25 \mathrm{~mm}$ and retained on sieve $20 \mathrm{~mm}$.

The batching of concrete was carried out by weighing the different constituent materials based on ten different mixes are as shown in Table 1. The materials were mixed thoroughly before adding the prescribed quantity of water and then further to produce fresh concrete. The fresh concrete of various mixes were then filled into a cone in three layers and their slump determine respectively in accordance with EN 12350 - 2 test standard. The fresh concrete was remixed properly and then filled into 3 moulds in approximately $50 \mathrm{~mm}$ layers with each layer given 25 strokes of the tamping rod (each mix ratio gave 3 moulds of concrete).

The concrete were towelled off level with the top of the mould and the specimen stored under a damp sack for 24 hours in the laboratory, before de-moulding and curing for 28 days. The compressive strengths of the various cubes were determined after 28 days of curing in accordance with BS 1881. Three samples were used for each mix and the average result adopted as the compressive strength.

$$
\text { Compressive strength }=\frac{\text { crushing }(\text { maximum }) \operatorname{load}(\mathrm{N})}{\text { cross sectional area of cube }\left(\mathrm{mm}^{2}\right)}
$$

\section{RESULTS AND ANALYSIS}

In order to achieve the objective of this work various laboratory tests were conducted on sand as fine aggregate and quarry dust as fine aggregate as well, also the concrete derived from them were tested in their fresh and hardened states. Below are presentation of data and a detailed discussion on the results obtained. The analysis is carried out in tables and graphs shown below. 
Table 1. Compressive strength of Quarry Dust.

\begin{tabular}{|c|c|c|c|c|c|c|}
\hline S/N & $\begin{array}{c}\text { Point of } \\
\text { observation }\end{array}$ & $\begin{array}{c}\text { Replica 1 } \\
(\mathrm{KN})\end{array}$ & $\begin{array}{c}\text { Replica 2 } \\
(\mathrm{KN})\end{array}$ & $\begin{array}{c}\text { Replica 3 } \\
(\mathrm{KN})\end{array}$ & $\begin{array}{c}\text { Cube } \\
\text { strength } \\
(\mathrm{KN})\end{array}$ & $\begin{array}{c}\text { Cube } \\
\text { strength } \\
\left(\mathrm{N} / \mathrm{mm}^{2}\right)\end{array}$ \\
\hline 1 & $Q_{1}$ & 470.77 & 483.50 & 463.36 & 472.54 & 21.00 \\
\hline 2 & $Q_{2}$ & 287.80 & 246.75 & 313.47 & 282.68 & 12.56 \\
\hline 3 & $Q_{3}$ & 265.90 & 245.53 & 258.33 & 256.59 & 11.04 \\
\hline 4 & $Q_{4}$ & 201.70 & 198.53 & 167.83 & 189.35 & 8.42 \\
\hline 5 & $Q_{5}$ & 397.69 & 368.91 & 345.60 & 370.73 & 16.48 \\
\hline 6 & $Q_{6}$ & 200.80 & 190.91 & 167.48 & 186.28 & 8.28 \\
\hline 7 & $Q_{7}$ & 185.23 & 176.26 & 182.87 & 181.45 & 8.06 \\
\hline 8 & $Q_{8}$ & 249.69 & 190.26 & 231.39 & 244.61 & 10.87 \\
\hline 9 & $Q_{9}$ & 250.37 & 248.61 & 265.55 & 254.84 & 11.33 \\
\hline 10 & $Q_{10}$ & 245.77 & 236.79 & 230.70 & 238.75 & 10.61 \\
\hline
\end{tabular}

Note: the cube strength in $\mathrm{N} / \mathrm{mm}^{2}$ is derived from dividing the force by $150 \times 150 \mathrm{~mm}^{2}$.

Table 2. Compressive strength of River Sand.

\begin{tabular}{|c|c|c|c|c|c|c|}
\hline $\mathrm{S} / \mathrm{N}$ & $\begin{array}{c}\text { Point of } \\
\text { observation }\end{array}$ & $\begin{array}{c}\text { Replica 1 } \\
(\mathrm{KN})\end{array}$ & $\begin{array}{c}\text { Replica 2 } \\
(\mathrm{KN})\end{array}$ & $\begin{array}{c}\text { Replica 3 } \\
(\mathrm{KN})\end{array}$ & $\begin{array}{c}\text { Cube strength } \\
(\mathrm{KN})\end{array}$ & $\begin{array}{c}\text { Cube strength } \\
\left(\mathrm{N} / \mathrm{mm}^{2}\right)\end{array}$ \\
\hline 1 & $S_{1}$ & 307.29 & 316.78 & 364.55 & 339.54 & 15.09 \\
\hline 2 & $S_{2}$ & 422.48 & 453.75 & 311.60 & 395.94 & 17.60 \\
\hline 3 & $S_{3}$ & 466.44 & 403.80 & 413.70 & 427.98 & 19.02 \\
\hline 4 & $S_{4}$ & 184.77 & 198.63 & 168.71 & 184.04 & 8.18 \\
\hline 5 & $S_{5}$ & 249.45 & 229.53 & 236.83 & 238.60 & 10.60 \\
\hline 6 & $S_{6}$ & 283.84 & 260.36 & 270.49 & 271.56 & 12.07 \\
\hline 7 & $S_{7}$ & 257.67 & 203.84 & 286.70 & 249.40 & 11.08 \\
\hline 8 & $S_{8}$ & 203.45 & 287.60 & 266.49 & 252.51 & 11.22 \\
\hline 9 & $S_{9}$ & 265.39 & 233.99 & 393.51 & 297.63 & 13.23 \\
\hline 10 & $S_{10}$ & 308.67 & 342.10 & 293.26 & 312.68 & 13.90 \\
\hline
\end{tabular}




\section{1. Slump values}

Table 3. Slump test for Concrete made with Quarry Dust.

\begin{tabular}{|c|c|c|}
\hline $\mathrm{S} / \mathrm{N}$ & Mix ratios & Quarry Dust Slump (cm) \\
\hline 1 & $0.45: 1: 1: 2.5$ & 0.0 \\
\hline 2 & $0.5: 1: 1.5: 3$ & 0.1 \\
\hline 3 & $0.55: 1: 2: 4$ & 0.0 \\
\hline 4 & $0.6: 1: 3: 6$ & 0.0 \\
\hline 5 & $0.475: 1: 2.5: 2.75$ & 2.3 \\
\hline 6 & $0.5: 1: 1.5: 3.25$ & 0.0 \\
\hline 7 & $0.525: 1: 2: 4.25$ & 0.0 \\
\hline 8 & $0.525: 1: 1.75: 3.5$ & 1.2 \\
\hline 9 & $0.55: 1: 2.25: 4.5$ & 0.0 \\
\hline 10 & $0.575: 1: 2.5: 5$ & 0.0 \\
\hline
\end{tabular}

Table 4. Slump test for Concrete made with River Sand.

\begin{tabular}{|c|c|c|}
\hline $\mathrm{S} / \mathrm{N}$ & Mix ratios & River Sand Slump $(\mathrm{cm})$ \\
\hline 1 & $0.45: 1: 1: 2.5$ & 5.0 \\
\hline 2 & $0.5: 1: 1.5: 3$ & 13.5 \\
\hline 3 & $0.55: 1: 2: 4$ & 9.6 \\
\hline 4 & $0.6: 1: 3: 6$ & 0.4 \\
\hline 5 & $0.475: 1: 2.5: 2.75$ & 4.8 \\
\hline 6 & $0.5: 1: 1.5: 3.25$ & 6.7 \\
\hline 7 & $0.525: 1: 2: 4.25$ & 7.0 \\
\hline 8 & $0.525: 1: 1.75: 3.5$ & 6.8 \\
\hline 9 & $0.55: 1: 2.25: 4.5$ & 14.6 \\
\hline 10 & $0.575: 1: 2.5: 5$ & 9.3 \\
\hline
\end{tabular}


Table 5. Grain size distribution.

\begin{tabular}{|c|c|c|}
\hline \multirow{2}{*}{ Sieve sizes } & QUARRY DUST & SAND \\
\cline { 2 - 3 } & Percentage Passing $\%$ & Percentage Passing \% \\
\hline $1.18 \mathrm{~mm}$ & 82 & 94 \\
\hline $600 \mu \mathrm{m}$ & 65 & 66 \\
\hline $425 \mu \mathrm{m}$ & 51 & 37 \\
\hline $300 \mu \mathrm{m}$ & 41 & 16 \\
\hline $212 \mu \mathrm{m}$ & 29 & 12 \\
\hline $150 \mu \mathrm{m}$ & 22 & 2 \\
\hline $75 \mu \mathrm{m}$ & 10 & 0 \\
\hline PAN & 0 & \\
\hline
\end{tabular}

Table 6. Percentage passing against sieve sizes (Quarry dust).

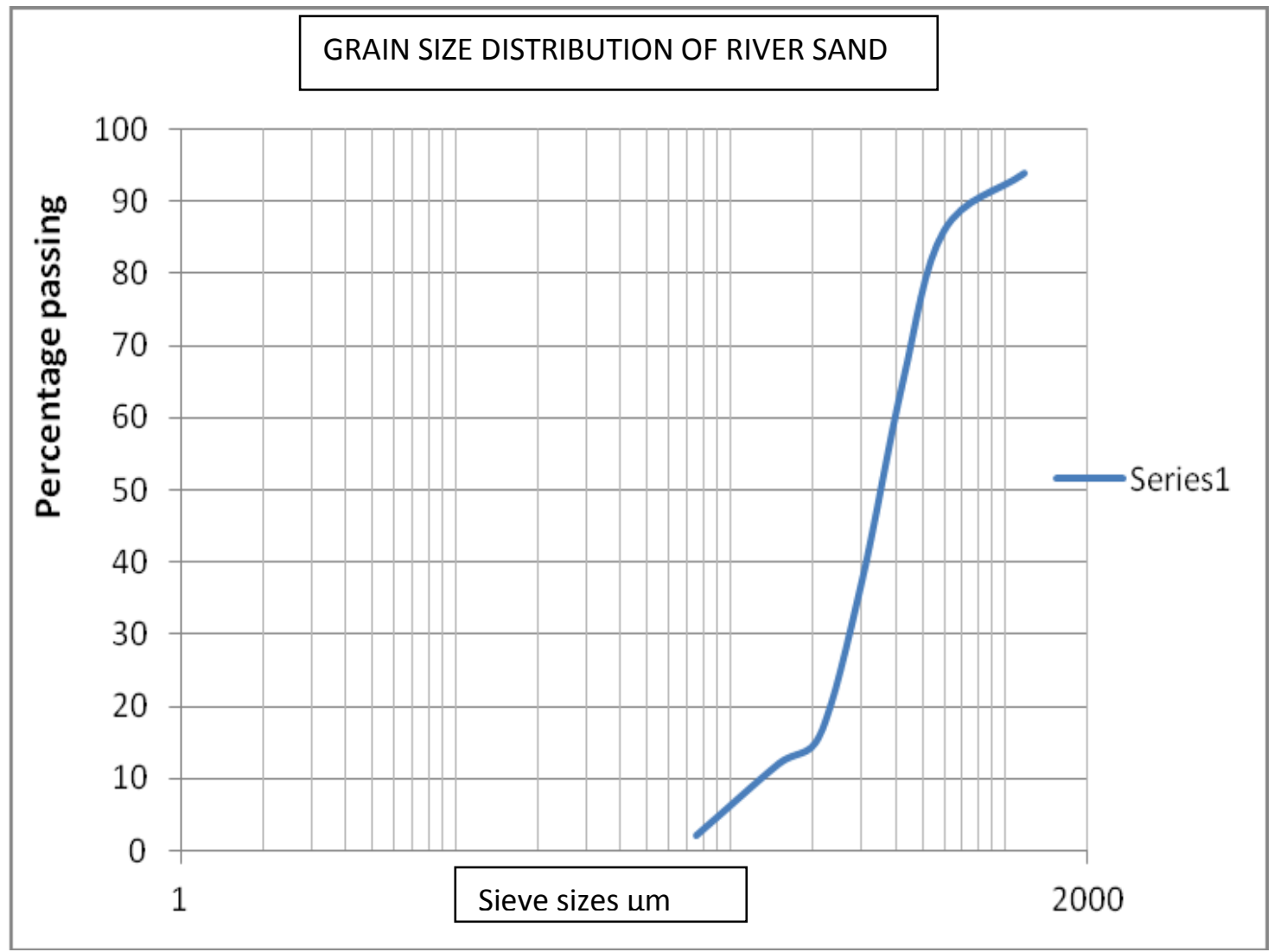

Table 7. Percentage passing against sieve sizes (River sand). 




Table 8. Density of concrete cube after curing for 28 days (Quarry Dust).

\begin{tabular}{|c|c|c|c|c|c|}
\hline Point of observation & $\begin{array}{c}\mathrm{A} \\
\mathrm{kg}\end{array}$ & $\begin{array}{c}\mathrm{B} \\
\mathrm{kg}\end{array}$ & $\begin{array}{c}\mathrm{C} \\
\mathrm{kg}\end{array}$ & $\begin{array}{c}\mathrm{AVG} \\
\mathrm{kg}\end{array}$ & $\begin{array}{c}\text { DENSITY } \\
\mathrm{Kg} / \mathrm{m}^{3}\end{array}$ \\
\hline$Q_{1}$ & 9.77 & 8.88 & 8.01 & 8.89 & 2633.09 \\
\hline$Q_{2}$ & 9.66 & 9.57 & 9.03 & 9.42 & 2791.11 \\
\hline$Q_{3}$ & 8.67 & 8.64 & 9.09 & 8.80 & 2607.41 \\
\hline$Q_{4}$ & 7.83 & 8.95 & 8.85 & 8.54 & 2530.37 \\
\hline$Q_{5}$ & 9.29 & 9.05 & 9.05 & 9.13 & 2705.19 \\
\hline$Q_{6}$ & 8.90 & 9.21 & 9.22 & 9.11 & 2699.26 \\
\hline$Q_{7}$ & 9.28 & 8.98 & 9.37 & 9.21 & 2728.89 \\
\hline$Q_{3}$ & 8.98 & 9.16 & 8.39 & 8.84 & 2619.26 \\
\hline$Q_{9}$ & 9.11 & 9.26 & 8.87 & 9.08 & 2690.37 \\
\hline$Q_{10}$ & 8.99 & 9.26 & 9.15 & 9.13 & 2705.19 \\
\hline
\end{tabular}

N/B: Density is derived from dividing the mass of cube in $\mathrm{kg}$ by volume of cube $\left(0.15^{*} 0.15^{*} 0.15\right)$ in metre. 
Table 9. Density of concrete after curing for 28 days (River sand).

\begin{tabular}{|c|c|c|c|c|c|}
\hline Point of observation & $\begin{array}{c}\mathrm{A} \\
\mathrm{kg}\end{array}$ & $\begin{array}{c}\mathrm{B} \\
\mathrm{kg}\end{array}$ & $\begin{array}{c}\mathrm{C} \\
\mathrm{kg}\end{array}$ & $\begin{array}{c}\mathrm{AVG} \\
\mathrm{kg}\end{array}$ & $\begin{array}{c}\text { DENSITY } \\
\mathrm{Kg} / \mathrm{m}^{3}\end{array}$ \\
\hline$S_{1}$ & 9.46 & 9.32 & 9.33 & 9.37 & 2776.30 \\
\hline$S_{2}$ & 9.45 & 8.98 & 9.32 & 9.25 & 2740.74 \\
\hline$S_{3}$ & 8.66 & 8.74 & 8.88 & 8.76 & 2595.56 \\
\hline$S_{4}$ & 8.96 & 9.33 & 8.97 & 9.09 & 2693.33 \\
\hline$S_{5}$ & 9.10 & 9.45 & 9.21 & 9.25 & 2740.74 \\
\hline$S_{6}$ & 9.52 & 8.93 & 8.83 & 9.09 & 2693.3 \\
\hline$S_{7}$ & 9.45 & 9.09 & 9.00 & 9.18 & 2720.00 \\
\hline$S_{8}$ & 8.89 & 9.25 & 9.15 & 9.10 & 2695.31 \\
\hline$S_{9}$ & 9.29 & 9.03 & 9.87 & 9.40 & 2784.20 \\
\hline$S_{10}$ & 9.00 & 9.57 & 9.58 & 9.38 & 2779.26 \\
\hline
\end{tabular}

Table 10. Comparison of the compressive strength of concrete made with quarry dust and that made with river sand as fine aggregate after 28 days curing $(\mathrm{Q}=$ quarry dust, $\mathrm{S}=$ river sand).

\begin{tabular}{|c|c|c|c|c|c|}
\hline $\mathrm{S} / \mathrm{N}$ & Mix ratios & $\begin{array}{c}\text { Water } \\
\text { content }\end{array}$ & $\begin{array}{c}\text { Cube strength, } \\
\mathrm{Q}\left(\mathrm{N} / \mathrm{mm}^{2}\right)\end{array}$ & Water content & $\begin{array}{c}\text { Cube } \\
\text { strength } \\
\mathrm{S}\left(\mathrm{N} / \mathrm{mm}^{2}\right)\end{array}$ \\
\hline 1 & $0.45: 1: 1: 2.5$ & 0.45 & 21.00 & 0.52 & 15.09 \\
\hline 2 & $0.5: 1: 1.5: 3$ & 0.50 & 12.56 & 0.49 & 17.60 \\
\hline 3 & $0.55: 1: 2: 4$ & 0.55 & 11.04 & 0.53 & 19.02 \\
\hline 4 & $0.6: 1: 3: 6$ & 0.60 & 8.42 & 0.54 & 8.18 \\
\hline 5 & $0.475: 1: 2.5: 2.75$ & 0.48 & 16.48 & 0.52 & 10.60 \\
\hline 6 & $0.5: 1: 1.5: 3.25$ & 0.50 & 8.28 & 0.52 & 12.07 \\
\hline 7 & $0.525: 1: 2: 4.25$ & 0.52 & 8.06 & 0.52 & 11.08 \\
\hline 8 & $0.525: 1: 1.75: 3.5$ & 0.53 & 10.87 & 0.52 & 11.22 \\
\hline 9 & $0.55: 1: 2.25: 4.5$ & 0.55 & 11.33 & 0.52 & 13.23 \\
\hline 10 & $0.575: 1: 2.5: 5$ & 0.57 & 10.61 & 0.52 & 13.90 \\
\hline
\end{tabular}




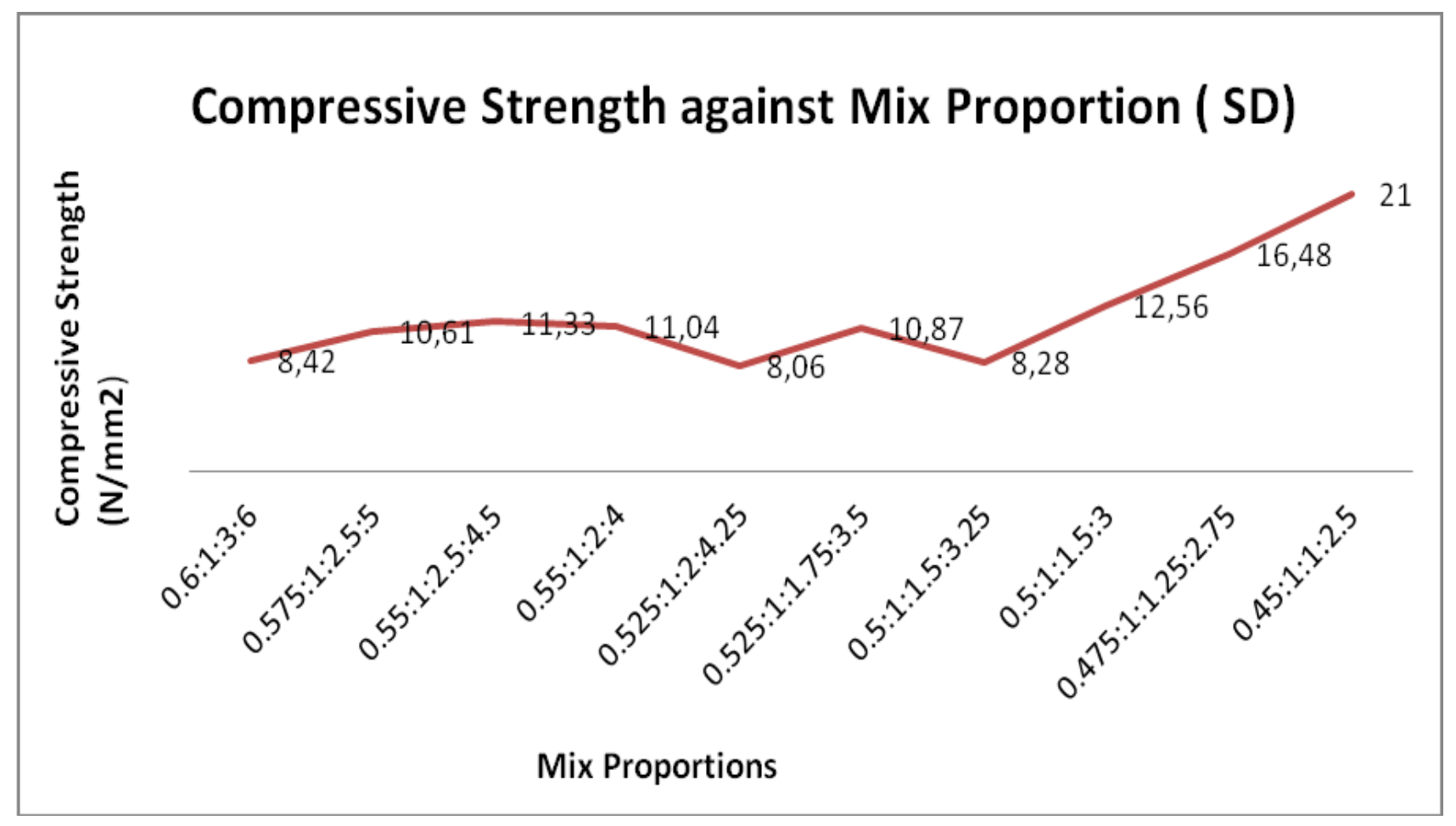

Figure 1. Graph of compressive strength against mix proportion (Quarry Dust).

\section{Compressive Strength against Mix Proportion ( QuarryDust)}

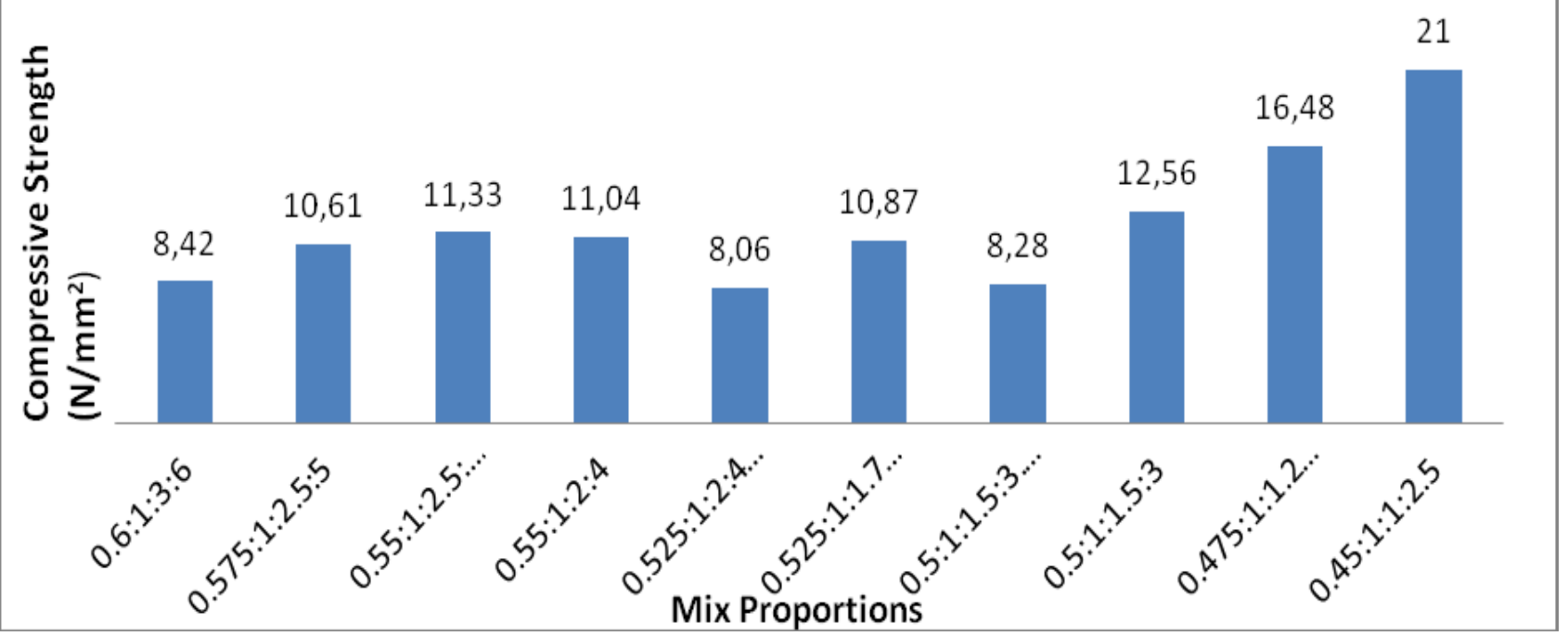

Figure 2. Bar chart showing compressive strength against mix proportion (Quarry Dust). 


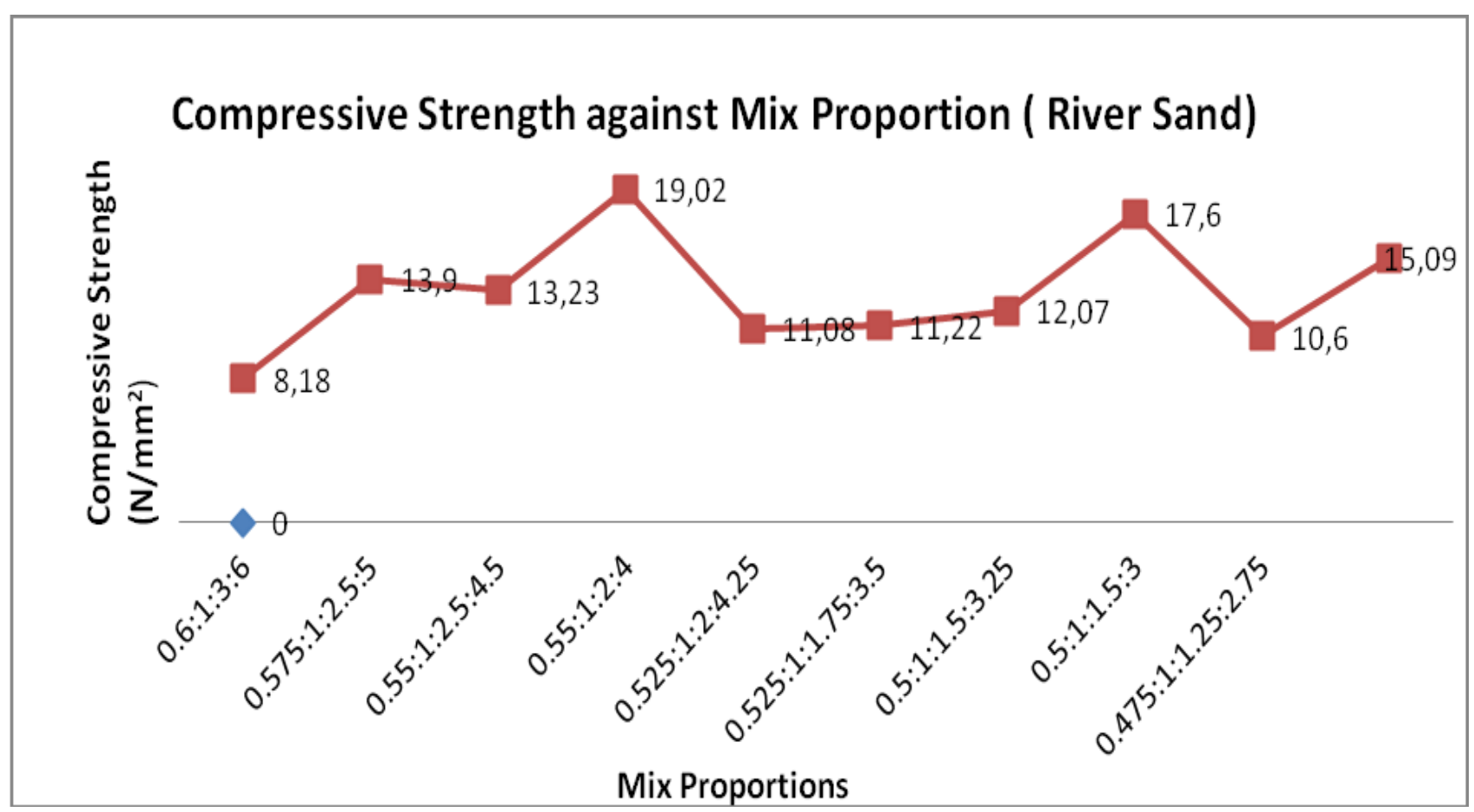

Figure 3. Graph of compressive strength against mix proportion (River Sand).

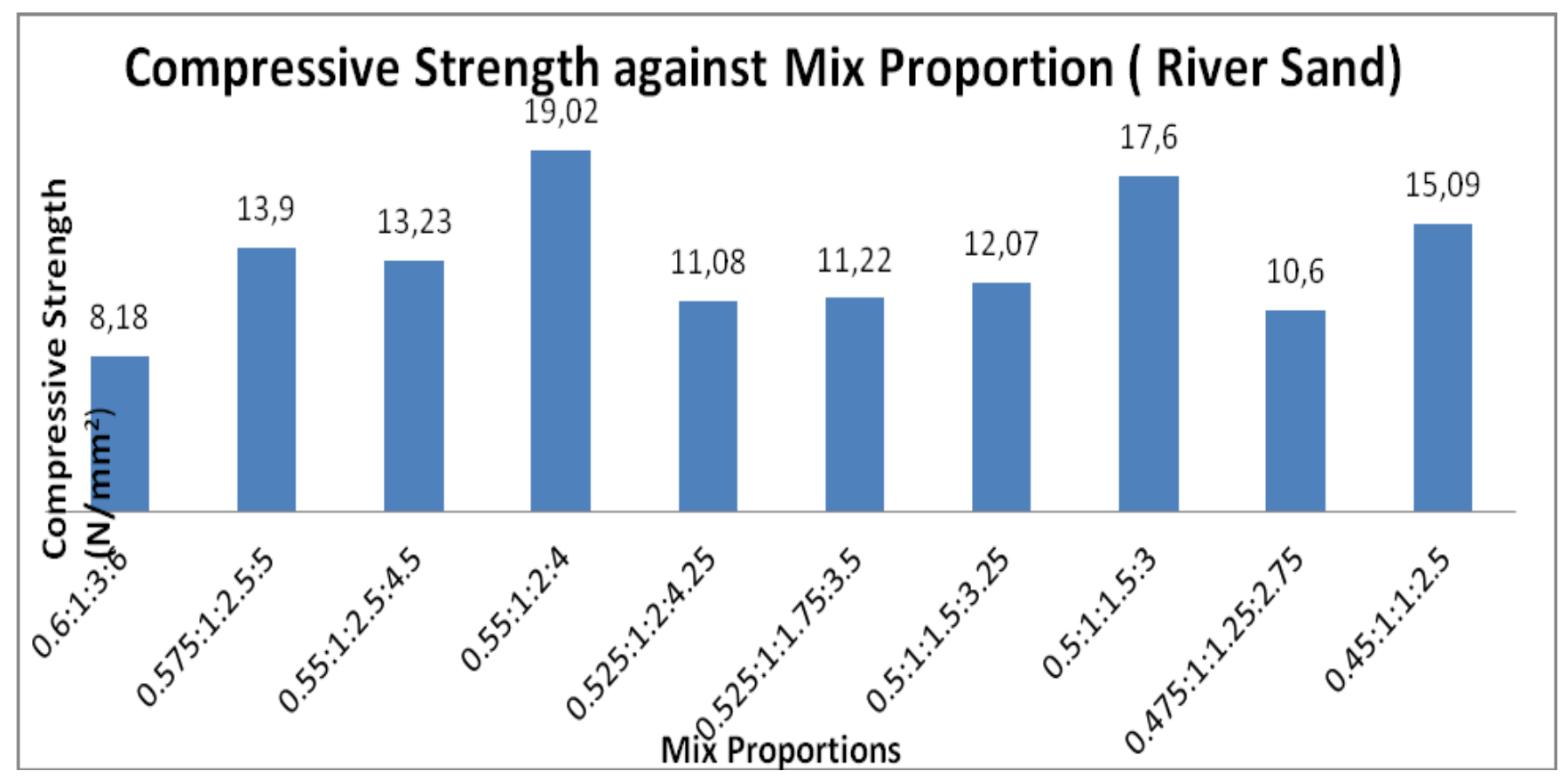

Figure 4. Bar chart showing compressive strength against mix proportion (River Sand). 
Table 11. Physical properties of the material used.

\begin{tabular}{|c|c|c|c|c|c|}
\hline \multirow{2}{*}{ PROPERTIES } & \multirow{2}{*}{ CEMENT } & \multicolumn{2}{|c|}{ FINE AGGREGATES } & \multicolumn{2}{c|}{$\begin{array}{c}\text { COARSE } \\
\text { AGGREGATES }\end{array}$} \\
\cline { 5 - 6 } & SAND & $\begin{array}{c}\text { QUARRY } \\
\text { DUST }\end{array}$ & $\begin{array}{c}\text { OVEN } \\
\text { Dry }\end{array}$ & $\begin{array}{c}\text { SURFACE } \\
\text { DRY }\end{array}$ \\
\hline SP. GRAVITY & 0.71 & 1.14 & 0.71 & 2.61 & 2.62 \\
\hline $\begin{array}{c}\text { WATER } \\
\text { ABSORPTION }\end{array}$ & - & - & - & \multicolumn{3}{|c|}{$0.5 \%$} \\
\hline
\end{tabular}

\section{2. Analysis of Results}

From the graphs and bar chart in Figure 1, 2, 3 and 4, it can be seen that as the mix proportion varies, the compressive strength also varies. The Compressive Strength is higher for the concrete made with quarry dust at some mix proportions and less at some other mix proportions compared to conventional concrete. For Instance, when the mix ratio was 1:1:2.5, the strength was $21 \mathrm{~N} / \mathrm{mm}$ for concrete made with quarry dust, but when the mix ratio was $1: 2.5: 2.75$, the strength reduced to $16.48 \mathrm{~N} / \mathrm{mm}$ and so on. The more the water content in the mix, the less the compressive strength of concrete made with quarry dust, this is because of the increase in free water content and this does not hold for conventional concrete. At the water/cement ratio of 0.49 there is an increase in Compressive Strength of concrete made with river sand concrete with corresponding decrease in compressive strength of concrete made with quarry dust content. This may be due to the high water absorption property of quarry dust which left insufficient water in the mix for the complete hydration of cement.

The quantity of coarse aggregate affected the strength of the concretes, the more the coarse aggregate in the mix, the less the strength in the quarry dust concrete as compared to river sand concrete. The reason for this is that as aggregate quantity increases, the quantity of fine aggregate in the concrete decreases, thereby reducing the aggregate surface area to absorb water, with consequence of increasing the free water content in the concrete. From the results the highest compressive strength is $21 \mathrm{~N} / \mathrm{mm}^{2}$, obtained for concrete containing quarry dust with mix ratio $1: 1: 2.5$ and w/c ratio of 0.45 , while the lowest strength is $8.06 \mathrm{~N} / \mathrm{mm}^{2}$, obtained with the same concrete made of quarry dust with mix ratio 1:2:4.5 and w/c ratio 0.525 . This is due to the difference in mix ratio and water cement ratio.

\section{CONCLUSION}

So quarry dust can effectively be used to replace river sand and reduce the negative impact this causes our environments due to constant plunging of our rivers and coastal areas in the name of extracting river sand for construction purposes. 


\section{References}

[1] Barritt C.M.H. (1984). Advance Building Construction. Vol.1 $2^{\text {nd }}$ Edition, J.W Arrowsmith Ltd, Bristol.

[2] BS 12 (1978). Specification for Portland cement. London British Standard Institute.

[3] BS 812 (1975). Method of Determination of Particle size and Shape. London British Standard Institute.

[4] BS 1881: Part 116 (1983). Method of determination of Compressive Strength of Concrete Cubes. London British Standard Institute.

[5] EN 12350: Part 2 (2000). Testing of Fresh Concrete Part 2: Slump Testing.

[6] Lohani T.K., Padhi M., Dash K.P., Jena S., Optimum Utilization of Quarry dust as Partial Replacement of Sand in Concrete. Int. Journal of Applied Science and Engineering Research 1(2) (2012).

[7] Rashid T.H.M.R., Hassan M.R., Mondol E.F., Influence of Stone Dust as Partial Replacing Material of Cement and Sand on Some mechanical Properties of Mortar. Int. Journal of Advance Structural and Geotechnical Engineering 02(02) (2013).

[8] Sukesh C., Krishna K.B., Sai Teja P.S.L., Rao J.K., Partial Replacement of Sand with Quarry in Concrete. Int. Journal of Innovative Technology and Exploring Engineering $5(2013)$.

[9] Troxel G.E., Davies H.E., Kelly J.W. (1968). Composition and properties of Concrete. (pp. 528). $2^{\text {nd }}$ edition McGraw Hill Books Company New York.

[10] Tahir C., Khaled M. (1999). Effect of Crushed Stone Dust on Properties of Concrete. Department of Civil Engineering Eastern Mediterranean University. Magusa, Mersin 10 , Turkey. 